\section{АНАЛІЗ ТЕНДЕНЦІЙ ФУНКЦІОНУВАННЯ РИНКУ ПРАЦІ}

СИВОЛАП Л. А., доктор економічних наук, доцент, Донецький державний університет управління

\section{ANALYSIS OF TRENDS IN THE LABOR MARKET FUNCTIONING}

\author{
SYVOLAP L., \\ Doctor of Science in Economics, \\ Associate Professor, Donetsk \\ State University of Management
}

У науковій статті визначено особливості та функції ринку праці. Охарактеризовано структуру сучасного ринку праці. Проаналізовано основні глобальні тенденції, які впливають на ринок праці. Досліджено кількість зареєстрованих безробітних та кількість вакансій за період 2019-2020 рр. Відповідно до видів економічної діяльності, визначено потребу у 2021 році в кадрах. Наведено попит у працівниках у 2021 році, відповідно до професійних навичок. Проаналізовано кількість вакансій у Донецькій області за період 2018-2021 роки. Представлено сучасну структуру вакансій у Донецькій області. Визначено проблеми у сучасному сегменті молодіжної зайнятості в Україні. Наведено заходи Кабінетом Міністрів України щодо забезпечення молодіжної зайнятості.

Ключові слова: ринок праці, безробіття, вакансій, професії, функції, структура.

В научной статье определены особенности и функции рынка труда. Охарактеризовано структуру современного рынка труда. Проанализированы основные глобальные тенденции, которые влияют на рынок труда. Исследовано количество зарегистрированных безработных и количество вакансий за период 2019-2020 гг. В соответствии с видами экономической деятельности, определена потребность в 2021 году в кадрах. Приведен спрос в работниках в 2021 году, согласно, профессиональных навыков. Проанализировано количество вакансий в Донецкой области за период 2018-2021 годы. Представлена современная структура вакансий в Донецкой области. Определены проблемы в современном сегменте молодежной занятости в Украине. Приведены мероприятия Кабинета Министров Украины по обеспечению молодежной занятости.

Ключевые слова: рынок труда, безработица, вакансий, профессии, функции, структура.

The scientific article defines the features and functions of the labor market. The structure of the modern labor market is characterized. The main global trends that affect the labor market are analyzed. The number of registered unemployed and the number of vacancies for the period 2019-2020 were studied. According to the types of economic activity, the need for staff in 2021 was determined. The demand for workers in 2021 is given, according to professional skills. The number of vacancies in the Donetsk region for the period 2018-2021 is analyzed. The modern structure of vacancies in Donetsk region is presented. Problems in the modern segment of youth employment in Ukraine are identified. The measures taken by the Cabinet of Ministers of Ukraine to ensure youth employment are presented.

Keywords: labor market, unemployment, vacancies, professions, functions, structure.

Постановка проблеми. Стан та розвиток ринку праці виступає одним з індикаторів соціально-економічного розвитку країни. Однак, в свою чергу, соціально-економічне становище в країні значно впливає на трансформаційні процеси, які відбуваються на ринку праці. Сьогодні значні зміни в економічній, соціальній, політичній, екологічній, 
інноваційно-технологічній сферах, обумовлюють стан та тенденції сучасного як світового, так й українського ринку праці. Тому $\epsilon$ актуальним систематичний моніторинг ринку праці, що дозволить визначити сучасні потреби в професійних та особистих якостях працівників, які необхідні роботодавцям.

Аналіз останніх досліджень i публікацій. Дослідженням теоретичних та практичних аспектів ринку праці займається багато науковців та фахівців сфери ринку праці, а саме: Чорна Н., Чорний Р. [1], Чатченко Т., Давидова І. [2], Швець О., [6] Дудін В., Ткаліч О. [7], яценко Л. [8]. Однак, мінлива ситуація на ринку праці робить дану тему досить актуальною для систематичного моніторингу та дослідження.

Метою статті $€$ аналіз тенденцій функціонування ринка праці в Україні в сучасних соціально-економічних умовах.

Виклад основного матеріалу. Ринок праці виступає сферою формування попиту та пропозиції на робочу силу. Учасниками ринку праці $€$ всі категорії працездатного населення які готові працювати за наймом або в режимі самозайнятості, а також роботодавці.

Основними функціями сучасного ринку праці $є$ такі [1]:

- суспільного поділу праці - розмежування роботодавців і найманих працівників за професіями, спеціальностями, галузями, регіонами;

- інформаційна - надання інформації щодо умов найму, рівня заробітної плати, вимог до якості робочої сили;

- посередницька - встановлює зв'язок між роботодавцями та найманими працівниками для задоволення взаємних інтересів та потреб щодо вигідних умов купівлі-продажу товару «робоча сила»;

- ціноутворююча - встановлює рівновагу між попитом і пропозицією робочої сили; під впливом дії закону вартості відбувається визначення витрат праці на відтворення робочої сили;

- регулююча - впливає на формування пропорцій суспільного виробництва, розвиток регіонів, сприяючи переміщенню робочої сили з одних регіонів в інші;

- стимулююча - ринок вимагає якісної робочої сили, стимулюючи найманих працівників поліпшувати свій професійний рівень знань та вмінь, кваліфікованість, компетентність.

На рис. 1 представлено структуру сучасного ринку праці, яка включає такі компоненти:

- інфраструктура ринку праці;

- суб'єкти ринку;

- безробіття та соціальні виплати;

- ринковий механізм (попит і пропозиція робочої сили, ціна праці, конкуренція);

- юридичні норми, економічні програми, тристоронні угоди та колективні договори;

- альтернативні види діяльності.

Сьогодні виконання робочих завдань стає автоматизованим, а роботи займають робочі місця людей. Окрім того, змінюються очікування компаній від співробітників. Ці зміни ставлять перед HRслужбами нові організаційні виклики та створюють перешкоди у пошуках талантів, підштовхують до несподіваних рішень і змушують працювати в умовах безпрецедентних ризиків, дестабілізації та соціальних потрясінь. 


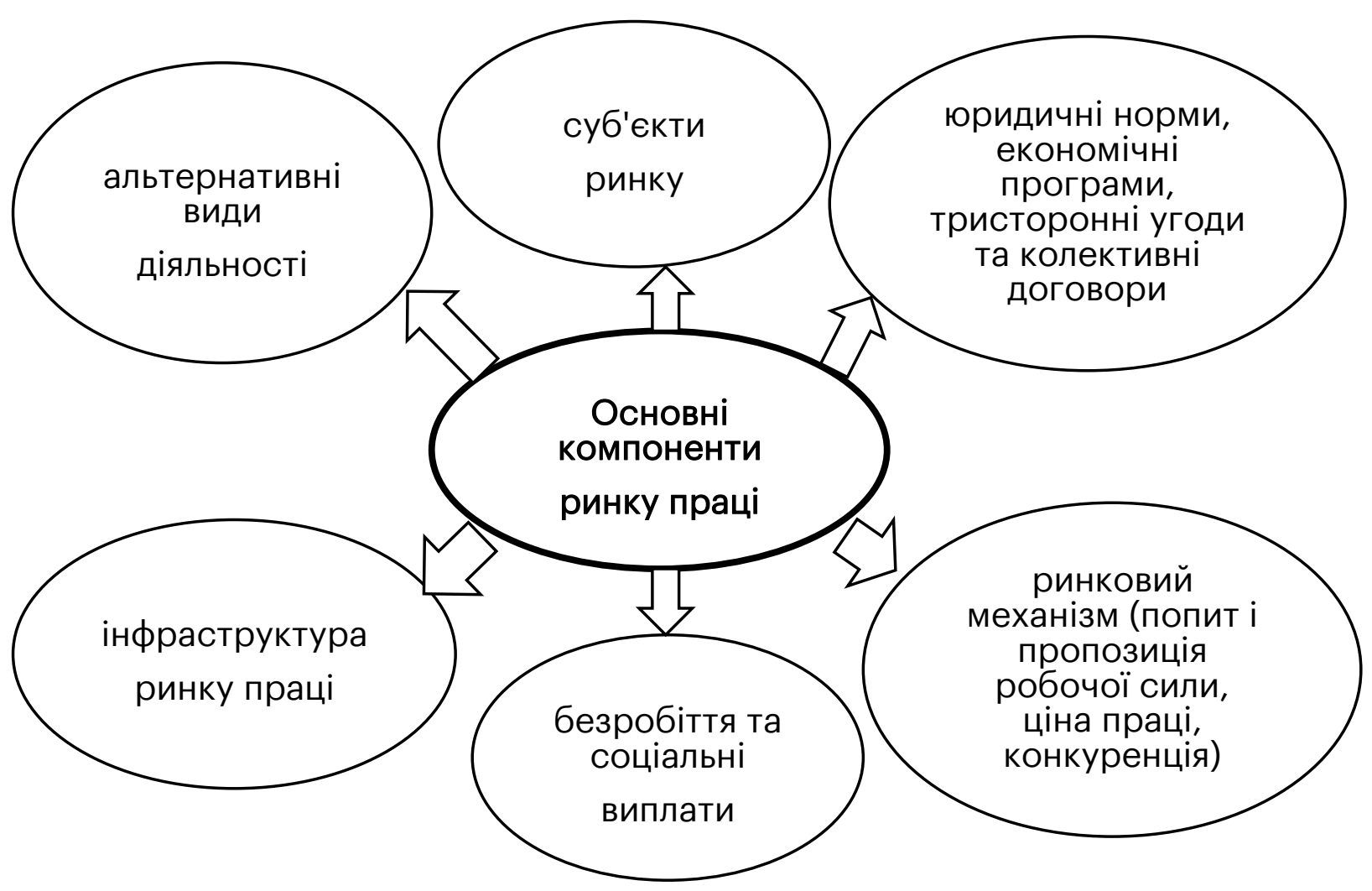

Рис. 1. Структура ринку праці [2]

Враховуючи новітні дослідження експертів ринку праці та організації праці, у світі сформувалось п'ять глобальних тенденцій (технологічний прогрес, демографічні зрушення, стрімка урбанізація, зміни в глобальній економіці, дефіцит ресурсів і зміни клімату), які суттєво впливають на розвиток ринка праці, зокрема на його попит та пропозицію. Для подальшого аналізу ринку праці охарактеризуємо ці основні глобальні тенденції.

Основні глобальні тенденції, які впливають на ринок праці [3]:

1. Технологічний прогрес (стрімкий розвиток технологічних інновацій). Автоматизація, роботизація і штучний інтелект, що стрімко розвиваються, суттєво перетворять якість і кількість доступних робочих місць. Технології здатні полегшити нам життя, підвищити продуктивність, рівень і тривалість життя, дозволяють зосередитися на особистісній самореалізації. При цьому вони загрожують соціальній стабільності, здатні викликати політичну й економічну напруженість, якщо економічні блага не розподілені рівномірно.

2. Демографічні зрушення (зміна чисельності, вікового складу $і$ розташування світового населення). За винятком невеликого числа регіонів населення світу старіє, чинячи тиск на бізнес, соціальні інститути та економіку. Збільшення тривалості життя впливає на бізнес-моделі, амбіції цінних співробітників і витрати на пенсійне забезпечення. Співробітники похилого віку будуть змушені освоювати нові навички і працювати далі. «Переозброєння» стане нормою. Брак робочої сили в ряді стрімко старіючих економік викличе гостру потребу в автоматизації і підвищенні продуктивності.

3. Стрімка урбанізація (значне зростання числа міського населення). За прогнозами ООН, до 2030 року в містах буде проживати 4,9 млрд людей, а до 2050 року число міських жителів по 
всьому світу зросте на 72\%. Уже зараз ВВП багатьох великих міст перевищує ВВП країн середнього розміру. У світі, що постійно змінюється, міста стануть впливовими факторами формування робочих місць.

4. Зміни в глобальній економіці (зміни в розстановці сил між розвиненими країнами i країнами, що розвиваються). У виграші залишаться країни, що швидко розвиваються, особливо з чисельною перевагою населення працездатного віку. Це країни, які проповідують принципи підприємницької активності, залучають інвестиційний капітал, вдосконалюють свою освітню систему. 3 розвитком технологій країни, що розвиваються, будуть стикатися з серйозними викликами, і без стабільних і значних капіталовкладень безробіття і міграція продовжать прогресувати. Розмиття середнього класу, різниця в рівні добробуту i скорочення робочих місць у зв'язку 3 розвитком автоматизації підвищують загрозу посилення соціальної нестабільності в країнах, що розвиваються.

5. Дефіцит ресурсів і зміни клімату (виснаження запасів викопного палива, екстремальні погодні умови, підвищення рівня моря i дефіцит води). До 2030 року прогнозований попит на енергію і воду зросте на 50\% і 40\% відповідно. Для задоволення потреб будуть створені нові робочі місця в таких сферах, як виробництво альтернативної енергії, нові технології, розробка нової продукції, переробка сміття і використання вторинних ресурсів. Мільйони людей, зайнятих у сфері традиційної енергетики, і сама галузь в цілому піддадуться стрімкій реорганізації.

Сьогодні весь сучасний світ потерпає від негативних наслідків, які виникли у наслідок пандемії COVID-19. Ринок праці також відчув негативні тенденції, які виникли через пандемію. Переважно це стосується попиту та пропозиції на ринку праці, що виражається у рівні безробіття та кількості вакансій. На рис. 2, 3 наведено кількість зареєстрованих безробітних та кількість зареєстрованих вакансій відповідно за період 2019-2020 рр.

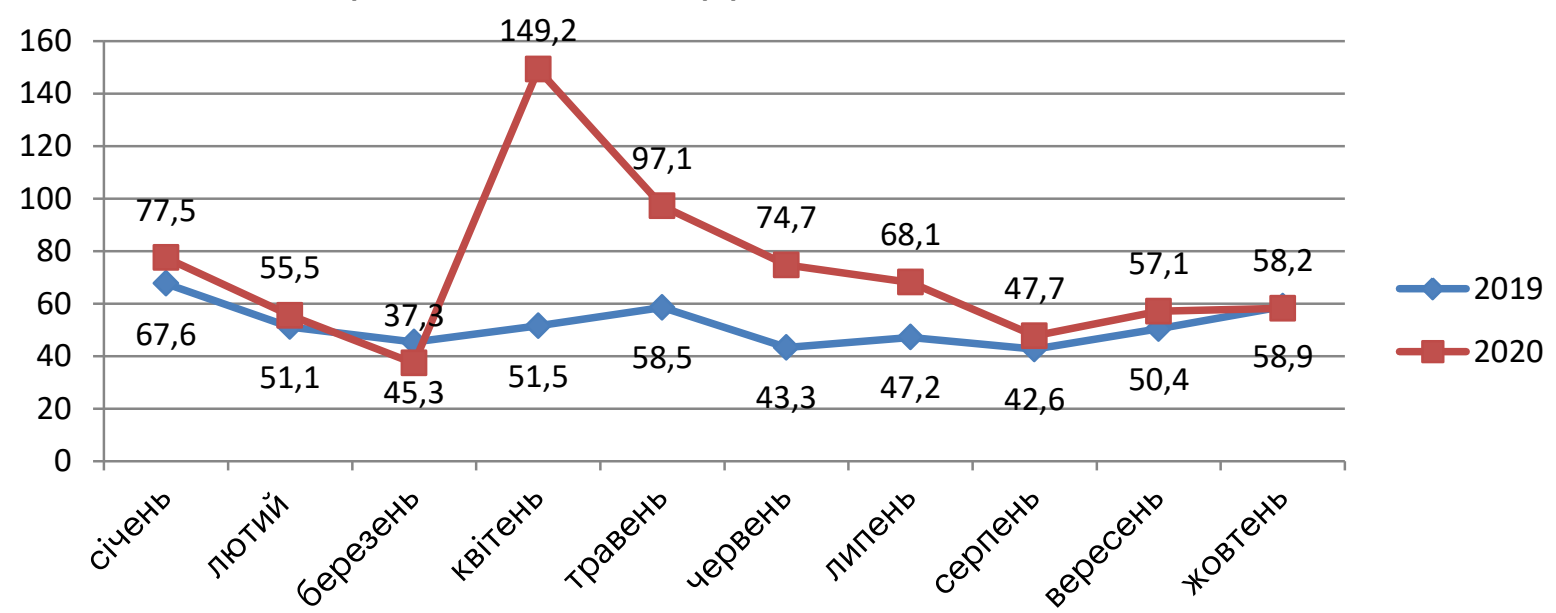

Рис. 2. Кількість зареєстрованих безробітних, тис. осіб [4]

Відповідно до рис. 2, бачимо що у 2020 р. по відношенню до 2019 р. та аналогічного місяця кількість безробітних в Україні зростає. Тільки у березні та жовтні 2020 р. відбулось не значне зменшення кількості безробітних в порівняні з жовтнем 2019 р. Найбільша кількість безробітних у 2020 році була у квітні. Ця ситуація пов'язана, 
переважно, з карантинними заходами, які були застосовані для боротьби з пандемією COVID-19. У наслідок чого значна кількість підприємств вимушена була перейти або в онлайн та дистанційний режим роботи, або зачинитися зовсім.

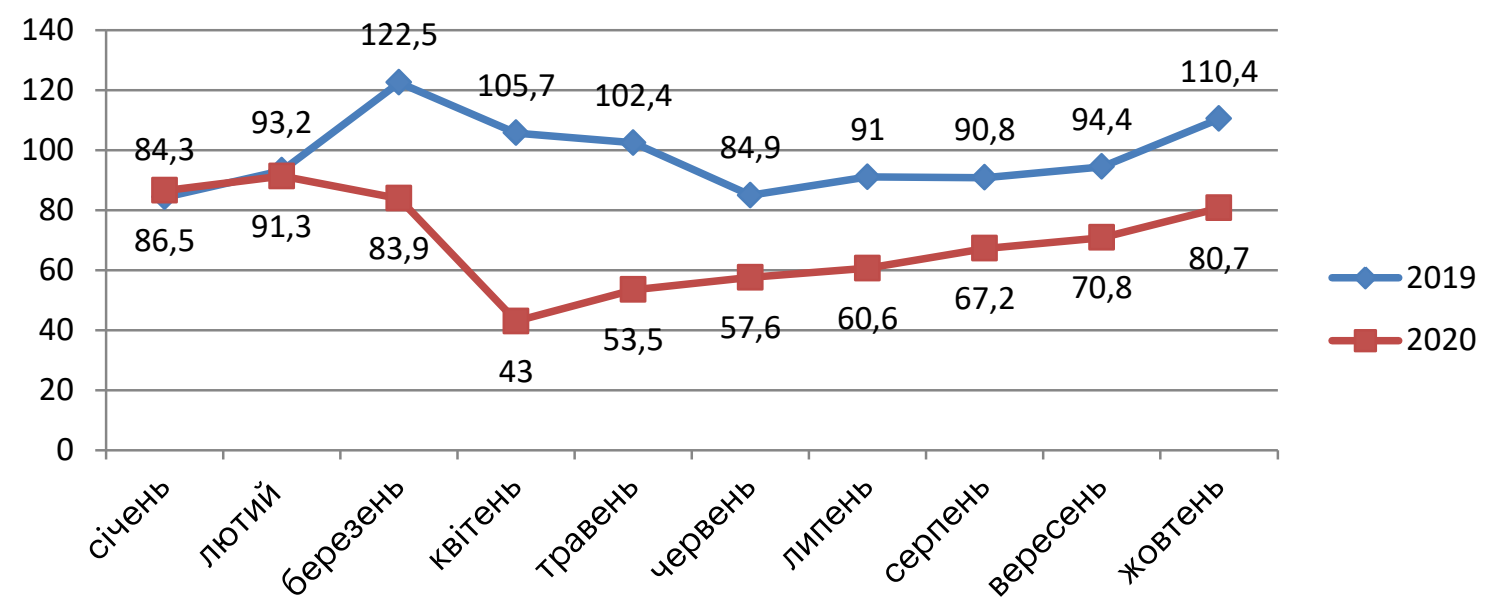

Рис. 3. Кількість зареєстрованих вакансій, тис. один [4]

На рис. 3 бачимо аналогічну ситуацію з рис. 2. Тобто загальна кількість вакансій у 2020 р. зменшилась у порівняні з 2019 р. Також на квітень 2020 р. прийшлось пікове зниження кількості вакансій, що теж пов'язано зі застосуванням карантинних заходів.

Спираючись на результати попередніх оцінок щодо додаткової потреби роботодавців у працівниках на 2021 рік [5], які були проведені Державною службою зайнятості, кількість вакансій становитиме 862 тис. одиниць, це на 4\% більше, ніж за 2020 рік. Ця тенденції відповідає Прогнозу економічного і соціального розвитку України на 2021-2023 роки, розробленого Міністерством розвитку економіки, торгівлі та сільського господарства України (постанова КМУ № 671) щодо зростання ВВП у 2021 році.

Згідно 3, вище зазначеною оцінкою щодо додаткової потреби роботодавців у працівниках на 2021 рік, Державна служба зайнятості визначила потребу у кадрах на 2021 рік за видами економічної діяльності та структуру попиту на працівників за основними розділами класифікації професій. Розглянемо дану потребу та попит детально.

За видами економічної діяльності переважатиме потреба у кадрах:

- у переробній промисловості - 17\% всіх вакансій. Найбільше пропозицій роботи очікується на підприємствах харчової промисловості, виробництва скла, цементу, гіпсових сумішей, виробництва одягу та оброблення деревини. Половина цих робочих місць зосереджена у 7 регіонах: Дніпропетровській, Житомирській, Львівській, Харківській, Київській, Полтавській та Вінницькій областях.

- у сільському господарстві - 15\% всіх вакансій. Понад 50\% цих вакансій у Вінницькій, Харківській, Полтавській, Черкаській, Одеській, Запорізькій та Кіровоградській областях.

- у сфері торгівлі - 15\% всіх вакансій. Третина вакансій підприємств торгівлі зосереджена у м. Києві, Дніпропетровській, Харківській та Львівській областях. 
- в освіті - 10\% всіх вакансій. Найбільша кількість вакансій закладів освіти очікується у м. Києві, Дніпропетровській, Харківській та Львівській областях.

- на транспорті та складському господарстві - 7\% всіх вакансій. Майже половина вакансій транспортних та складських підприємств зосереджена у м. Києві, Харківській, Дніпропетровській, Львівській, Київській та Полтавській областях.

- державному управлінні й обороні - 7\% всіх вакансій. Майже половина вакансій установ державного управління та оборони зосереджена у м. Києві, Харківській, Хмельницькій, Львівській, Дніпропетровській та Житомирській областях.

За основними розділами класифікації професій передбачається, що у 2021 році структура попиту на працівників буде наступною:

- 24\% складатиме потреба у робітниках 3 обслуговування устаткування та машин (водій, водій тролейбуса, водій навантажувача, машиніст екскаватора, дорожній робітник, тракторист, машиніст котельної, оператор заправних станцій, токар, оператор верстатів та установок);

- 16\% складатиме потреба у представниках найпростіших професій (підсобний робітник, комірник, укладальник-пакувальник, двірник, прибиральник, сторож, вантажник, кур'єр);

- 15\% становитиме потреба у кваліфікованих робітниках 3 інструментом (швачка, слюсар-ремонтник, слюсар-сантехнік, електрогазозварник, електромонтер 3 ремонту та обслуговування електроустаткування, верстатник деревообробних верстатів, монтер колії, робітник з комплексного обслуговування й ремонту будинків, столяр, пекар);

- 14\% становитиме попит на працівників сфери торгівлі та послуг (продавець, кухар, поліцейський, молодша медична сестра, соціальний робітник, помічник вихователя, перукар, охоронник);

- 10\% складатиме попит на фахівців (бухгалтер, інспектор кадрів, медична сестра, фармацевт);

- 9\% складатиме попит на професіоналів (вчитель, викладач, вихователь, програміст, інженер, технолог, економіст, юрист, провізор);

- 6\% становитиме потреба у керівниках та менеджерах (менеджер, начальник відділення зв'язку, керівник структурних підрозділів, головний бухгалтер, головний інженер, завідувач складу);

- 4\% становитиме потреба у технічних службовцях (касир торговельного залу, адміністратор, реєстратор медичний, секретар, приймальник замовлень, листоноша (поштар), оператор поштового зв'язку);

- 3\% складатиме попит на кваліфікованих робітників сільського, лісового та рибного господарства (робітник 3 комплексного обслуговування сільськогосподарського виробництва, робітник фермерського господарства, рибалка прибережного лову, лісник, робітник на лісогосподарських роботах, овочівник, тваринник, оператор машинного доїння, птахівник).

Якщо проаналізувати тенденції щодо кількості вакансій у Донецькій області, то з рис. 4 видно, що у 2020 р. їх кількість 
зменшилась на 31\% у порівнянні з 2018 р. А у 2021 році прогнозується незначне збільшення кількості вакансій (+7\%) в порівнянні з 2020 р.

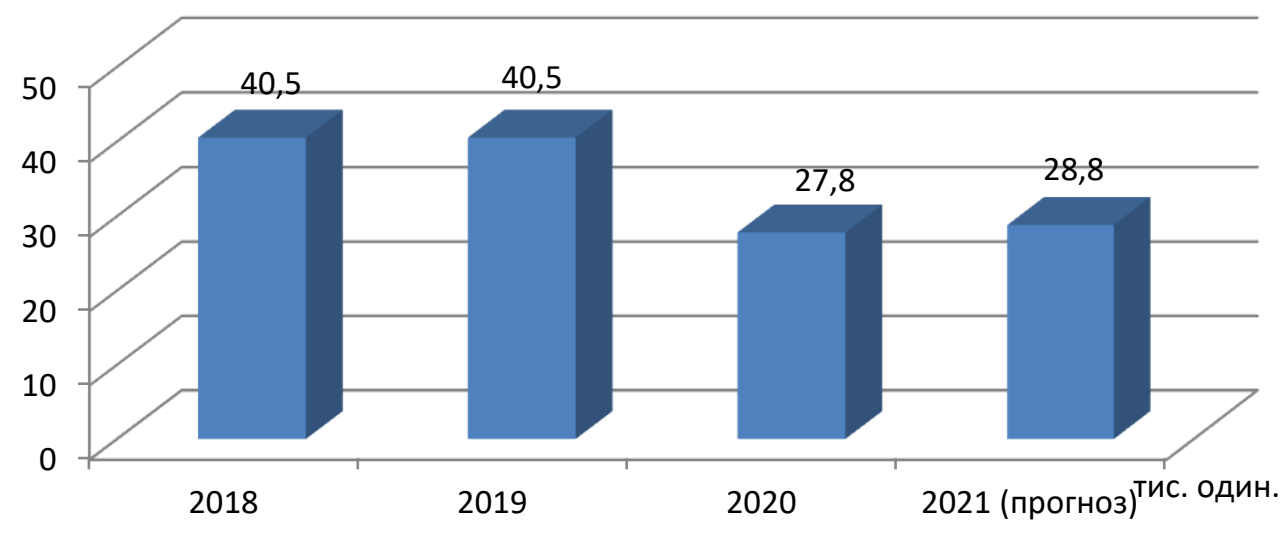

*Побудовано автором на базі джерела [5]

Рис. 4. Кількість вакансій у Донецькій області за період 2018-2021 pp.

Структуру вакансій у Донецькій області за видами економічної діяльності та за професійними групами представлено на рис. 5.

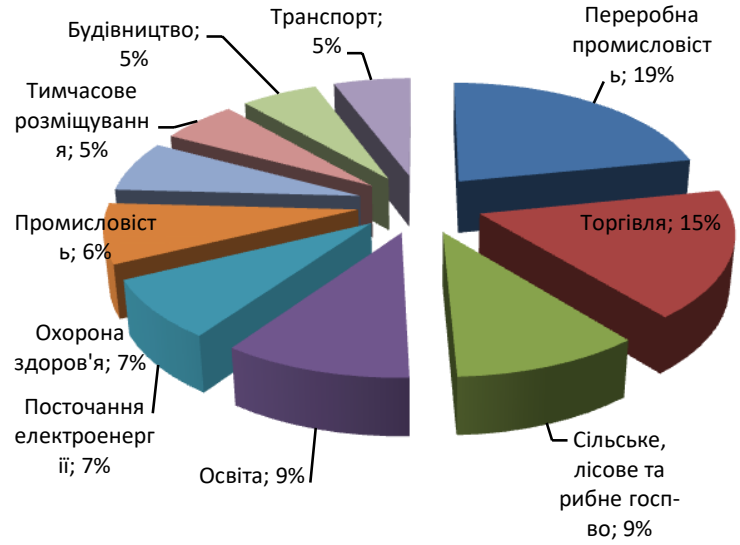

а) За видами економічної діяльності

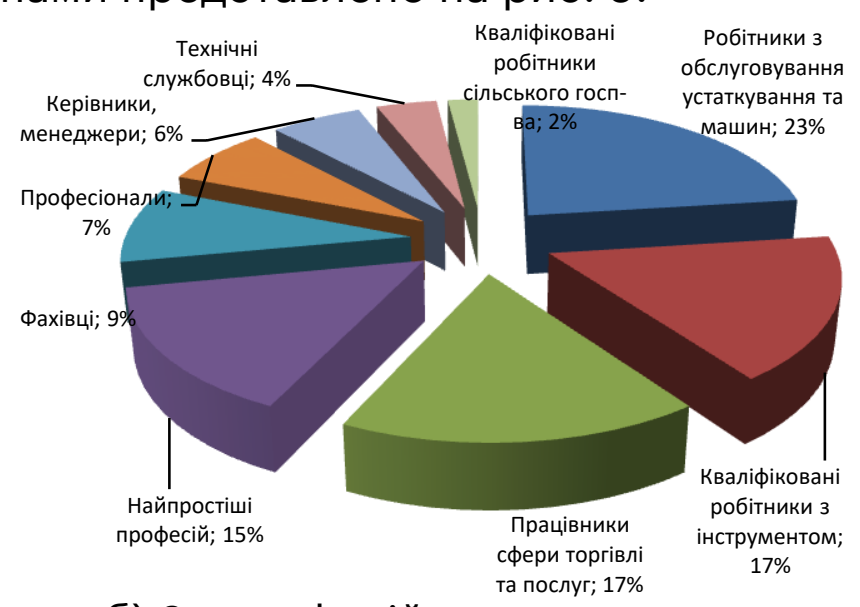

б) За професійними групами

* Побудовано автором на базі джерела [5]

Рис. 5. Структура вакансій у Донецькій області

Таким чином, за видами економічної діяльності переважну долю вакансій складають вакансії у переробній промисловості (19\%) та торгівлі (15\%). Інші види економічної діяльності мають більш рівномірний дольовий розподіл. Відповідно професійним групам найбільшу долю вакансій складають робітники 3 обслуговування устаткування та машин (23\%).

В реаліях сьогодення однією з основних проблем вітчизняного ринку праці $€$ працевлаштування молоді. Молоді люди відчувають себе незахищеними та не можуть адаптуватися до реалій сучасного соціально-економічного життя. Однак, парадоксальним $\in$ те що молодіжні трудові ресурси України мають конкурентні переваги, а саме: високий рівень освіти, навички колективної праці та трудові традиції, розвинуте відчуття справедливості й відповідальності та інше. 
Отже, сучасний сегмент молодіжної зайнятості в Україні характеризується наявністю низки проблем, зокрема [6]:

- низьким рівнем економічної активності осіб наймолодшої вікової категорії;

- високим рівнем безробіття, що знижується у старших вікових групах молоді;

- структурним дисбалансом між попитом та пропозицією праці;

- значним рівнем неформальної зайнятості;

- залучення молоді до нестабільної праці;

- робота молоді за спеціальністю нижчої кваліфікації у порівнянні зі здобутою освітою;

- низькою поінформованістю абітурієнтів про попит вакансій як на регіональному, так і національному ринку праці;

- високими професійними вимогами роботодавців до молоді;

- обов'язковою наявністю стажу роботи не менше трьох років;

- соціальна незахищеність більшості молодих людей державою;

- неможливість зайнятися підприємництвом через відсутність стартового капіталу та неможливість отримати його у кредит через великі відсотки тощо.

Нинішній стан безробіття пояснюється, зокрема, неузгодженістю освіти та потреб ринку праці. Проблему ускладнено поєднанням двох чинників:

1) Недостатня ефективність державної політики щодо дотримання стандартів соціально-трудових відносин, професійної орієнтації та соціальної підтримки молоді з низькою кваліфікацією, системи освіти та підготовки кадрів, а також розвитку підприємництва.

2) Молоді люди у вирішенні власних проблем значною мірою зорієнтовані на допомогу «третіх осіб» (батьків, друзів, держави) [7].

Для держави залучення молоді до трудової активності - це стратегічні інвестиції в суспільний розвиток. Тому реалізація активної політики щодо молодіжної зайнятості з застосуванням прозорих та ефективних механізмів стимулювання роботодавців до працевлаштування молоді, мотивація молодих людей до трудової активності та подолання стереотипних уявлень роботодавців стосовно їх низького професіоналізму має стати пріоритетом державної політики у найближчій перспективі, зокрема через реалізацію низки наступних заходів [6]:

Кабінетом Міністрів України:

1. У плані заходів щодо реалізації Концепції Державної цільової соціальної програми «Молодь України» на 2020-2025 передбачити:

- заходи, спрямовані на стимулювання підприємницької ініціативи молоді шляхом запровадження податкових стимулів для цієї категорії підприємців терміном на перші три роки та забезпечення для них пільгового кредитування;

- створення пільгових умов отримання ліцензій на певні види діяльності (у першу чергу у сфері новітніх технологій) для молоді;

- механізми мотивації роботодавців до працевлаштування молодих спеціалістів (наприклад, квотування чисельності молодих фахівців на підприємствах та фінансова підтримка роботодавців на етапах апробації та адаптації молоді). 
2. Прискорити прийняття Концепції державної політики у сфері професійної освіти, підготовленої МОН, та розробити необхідний для ії реалізації план заходів 3 метою здійснення системної реформи професійної освіти, спрямованої на реалізацію трьох базових завдань та їх ключових компонентів: забезпечення якості професійної освіти; децентралізацію управління та фінансування; впровадження проєктів публічно-приватного партнерства у сфері професійної освіти і навчання, встановлення взаємозв'язку між змістом вищої освіти і потребами ринку праці.

3. Встановити спеціальною постановою головним критерієм надання дотації, передбаченої Законом України «Про забезпечення молоді, яка отримала вищу або професійно-технічну освіту, першим робочим місцем 3 наданням дотації роботодавцю», прийняття на роботу молоді з окремих груп, найменш конкурентоспроможних на ринку праці.

4. Відновити роботу Міжгалузевої ради з професійно-технічної освіти при Кабінеті Міністрів України.

5. Розглянути питання про створення спеціального фонду підготовки робітничих кадрів за рахунок визначених законом обов'язкових відрахувань з доходів підприємств шляхом перерозподілу частки єдиного внеску для Фонду соціального страхування на випадок безробіття до створеного фонду [8].

Висновок та перспективи подальших досліджень. Отже, ринок праці - це така сфера, де відбувається купівля та продаж робочої сили. А також він виступає індикатором сучасного соціально-економічного становища країни. Зарубіжні та відчинянні ринки праці знаходяться на шляху значних трансформаційних процесів. Це свідчить про певні зміни у вимогах до кандидатів на вакантні місця, що говорить про необхідність оволодіння новими професійними та особистісними якостями, які відповідатимуть реаліям сьогодення. Пандемія COVID-19 стала викликом для економіки, промисловості та інших сфер народного господарства. Це наочно відобразилось й на ринку праці, де значно підвищився рівень безробіття та знизився попит на робочу силу. Однак, прогнозні очікування експертів говорять про позитивну тенденцію у підвищенні попиту на робочу силу. Однією 3 головних проблем сучасного ринку праці України $€$ працевлаштування молоді. Наразі державна політика сформувала та продовжує удосконалювати механізми та інструменти працевлаштування молодого працездатного населення країни.

Література:

1. Чорна Н., Чорний Р. Ринок праці України: сучасні виклики. Економічний часопис Східноєвропейського національного університету імені Лесі Українки, 2020. №1. С. 64-73.

2. Чатченко Т. В., Давидова І. А. Ринок праці в Україні: сучасний стан і перспективи розвитку. Бізнесінформ, 2019. №7. С. 170-174.

3. Майбутнє ринку праці Протиборство тенденцій, які будуть формувати робоче середовище в 2030 році. URL: https://www.pwc.com/ua/uk/survey/2018/workforce-of-the-futureukr.pdf.

4. Ринок праці 2021: хто буде з роботою і кому піднімуть зарплату. URL: https://happymonday.ua/rynok-pratsi-2021.

5. Попередні оцінки щодо додаткової потреби роботодавців у працівниках на 2021 рік. URL: https://www.dcz.gov.ua/sites/default/files 
/infofiles/poperedni ocinky shchodo potreby robotodaciv u pracivnyka h.pdf.

6. Швець О. В. Проблеми розвитку ринку праці молоді та державні пріоритети його регулювання. Український журнал прикладної економіки, 2020. Том 5. № 3. С. 17-25.

7. Дудін В., Ткаліч О. Праця замість молодості: загрози для молоді на ринку праці. URL: https://commons.com.ua/ru/pratsya-zamistmolodosti-zagrozi-dlya-molodi-na-rinkupratsi/.

8. Яценко Л. Д. Проблеми молодіжної зайнятості в Україні та шляхи їх подолання. Національний інститут стратегічних досліджень. 2019. URL: https://niss.gov.ua/sites/default/files/2019-8F.pdf.

References:

1. Chorna N., Chornyj R. Rynok praci Ukrajiny: suchasni vyklyky. Ekonomichnyj chasopys Skhidnojevropejsjkogho nacionaljnogho universytetu imeni Lesi Ukrajinky, 2020. \#1. S. 64-73.

2. Chatchenko T. V., Davydova I. A. Rynok praci v Ukrajini: suchasnyj stan i perspektyvy rozvytku. Biznesinform, 2019. \#7. S. 170-174.

3. Majbutnje rynku praci Protyborstvo tendencij, jaki budutj formuvaty roboche seredovyshe $v 2030$ roci. URL: https://www.pwc.com/ua/uk/survey/2018/workforce-of-the-futureukr.pdf.

4. Rynok praci 2021: khto bude z robotoju i komu pidnimutj zarplatu. URL: https://happymonday.ua/rynok-pratsi-2021.

5. Poperedni ocinky shhodo dodatkovoji potreby robotodavciv u pracivnykakh na 2021 rik. URL: https://www.dcz.gov.ua/sites/default/files/infofiles/poperedni_ocinky_s hchodo_potreby_robotodaciv_u_pracivnykah.pdf.

6. Shvecj O. V. Problemy rozvytku rynku praci molodi ta derzhavni priorytety jogho reghuljuvannja. Ukrajinsjkyj zhurnal prykladnoji ekonomiky, 2020. Tom 5. \# 3. S. 17-25.

7. Dudin V., Tkalich O. Pracja zamistj molodosti: zaghrozy dlja molodi na rynku praci. URL: https://commons.com.ua/ru/pratsya-zamistmolodosti-zagrozi-dlya-molodi-na-rinkupratsi/.

8. Jacenko L. D. Problemy molodizhnoji zajnjatosti $v$ Ukrajini ta shljakhy jikh podolannja. Nacionaljnyj instytut strateghichnykh doslidzhenj. 2019. URL: https://niss.gov.ua/sites/default/files/20198F.pdf.

The scientific article reveals the essence of the labor market. Its functions are defined, namely the following: social division of labor; informational; mediation; pricing; regulatory; stimulating. The structure of the modern labor market is presented, which consists of the following elements: labor market infrastructure; market participants; unemployment and social benefits; market mechanism (labor supply and demand, labor prices, competition); legal norms, economic programs, tripartite agreements and collective agreements; alternative activities. Based on the latest research of labor market and labor organization experts in the world, five global trends (technological progress, demographic changes, rapid urbanization, changes in the global economy, scarcity of resources and climate change) that significantly 
affect the development of the labor market, in particular on its supply and demand. In terms of the number of registered unemployed and the number of vacancies for the period 2019-2020, the negative impact of the COVID-19 pandemic on the labor market has been determined. The date of the State Employment Service, which determined the need for staff for 2021 by type of economic activity (in the processing industry, agriculture, trade, education, transport and warehousing, public administration and defense) and the structure of demand for workers by the main sections of the classification of the professions. The number of vacancies and their structure in the Donetsk region for the period 20182021 are analyzed. It is noted that in today's realities one of the main problems of the domestic labor market is youth employment. It is determined that the current segment of youth employment in Ukraine is characterized by a number of problems, for example: low level of economic activity of the youngest age group; high unemployment, which decreases in older age groups of young people; structural imbalance between labor supply and demand; significant level of informal employment and more. The measures taken by the Cabinet of Ministers of Ukraine to ensure youth employment are presented.

\section{ІННОВАЦІЙНИЙ РОЗВИТОК ЕКОНОМІЧНИХ СИСТЕМ: ДЕРЖАВНИЙ I РЕГІОНАЛЬНИЙ АСПЕКТИ ФІНАНСУВАННЯ}

ДЯТЛОВА Ю. В., доктор економічних наук, доцент, завідувач кафедри фінансів та обліку,

ТАРАСЕНКО Д. Л., доктор економічних наук, доцент, декан факультету права і

публічного управління, Донецький державний університет управління

\section{INNOVATIVE DEVELOPMENT OF ECONOMIC SYSTEMS: STATE AND REGIONAL FINANCING ASPECTS}

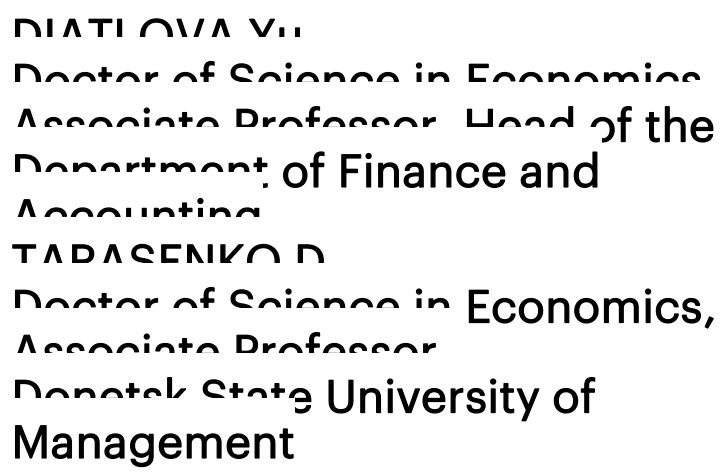
Management

Встановлено сучасні тенденції фінансування інноваційного розвитку економічних систем на рівні держави та регіонів. Акцентовано увагу на специфіці та вкладі регіонів у створення фінансових передумов інноваційного розвитку. Показано, що недосконалість механізму фінансового стимулювання зумовлюе нерозвиненість інноваційної інфраструктури та обмеженість ії участі в інноваційних процесах. Запропоновано рівні пріоритетів фінансування інноваційної діяльності та відповідні їм джерела. Обгрунтовано розширення номенклатури показників.

Ключові слова: інноваційний розвиток економіки, державний i регіональний аспекти, фінансове забезпечення, джерела, банківське 